\title{
Cyanopeptoline CB071: A Cyclic Depsipeptide Isolated from the Freshwater Cyanobacterium Aphanocapsa sp.
}

\author{
Hyukjae CHOI, ${ }^{a}$ Sun Kwan OH, ${ }^{b}$ Wonho YIH, ${ }^{b}$ Jungwook CHIN,${ }^{a}$ Heonjoong Kang, ${ }^{*, a}$ and \\ Jung-Rae RHO ${ }^{*}, b$ \\ ${ }^{a}$ Center for Marine Natural Products and Drug Discovery, School of Earth and Environmental Sciences, Seoul National \\ University; NS-80, Seoul 151-747, Korea: and ${ }^{b}$ Department of Oceanography, Kunsan National University; Jeonbuk \\ 673-701, Korea. $\quad$ Received April 1, 2008; accepted May 23, 2008; published online May 27, 2008
}

\begin{abstract}
Cyanopeptolin CB071 (1), a trypsin inhibitor, was isolated from the freshwater cyanobacterium Aphanocapsa sp. Its complete structure was determined by detailed NMR spectroscopy and MS analyses, along with chemical reactions. The compound showed inhibition of trypsin at a concentration of $\mathrm{IC}_{50}=2.5 \mu \mathrm{M}$.
\end{abstract}

Key words cyanopeptolin CB071; Aphanocapsa sp.; trypsin inhibitor; 2D NMR

Cyanobacteria (blue-green algae) have been known to produce a large number of oligopeptides causing toxicity and protease inhibition. ${ }^{1,3)}$ In particular, Microcystis sp. contains microcystin-type hepatotoxins and a non-toxic 6-amino acidmembered cyclic depsipeptide possessing the modified amino acid 3-amino-6-hydroxy-piperidone (Ahp).,5) This depsipeptide was named cyanopeptolin or micropeptin and many compounds in the same structural class have been found to inhibit trypsin or chymotrypsin. Such oligopeptides have also been reported to be produced from other cyanobacteria like Nostoc sp. and Oscillatoria sp. ${ }^{6-8)}$ During the process of studying the protease inhibition caused by cyanobacteria, we isolated a new derivative-cyanopeptolin CB071 (1)-containing the Ahp moiety from the tentatively identified Aphanocapsa sp. which is closely similar to Microcystis $\mathrm{sp}$. Here we present the isolation and structure determination of 1 that was achieved using spectral data and chemical reactions.

The $90 \%$ methanolic extract from the cultured cyanobacterium Aphanocapsa sp. (1001) was partitioned between butanol and water. The butanolic layer $(1.1 \mathrm{~g})$ was subjected to LH20 column chromatography, eluting with $100 \% \mathrm{MeOH}$, to obtain 5 fractions. The first fraction was purified with reversed phased HPLC with $30 \%$ aqueous $\mathrm{MeOH}$ to yield $\mathbf{1}$ (9.3 mg).

Cyanopeptolin CB071 (1) was isolated as a colorless amorphous powder and its molecular formula was determined as $\mathrm{C}_{48} \mathrm{H}_{75} \mathrm{~N}_{10} \mathrm{O}_{13} \mathrm{Cl}$ based on the protonated molecular ion peak of [M+H] ${ }^{+}$at $m / z 1035.5259(\Delta-2.3 \mathrm{mmu})$, corresponding to 16 unsaturation degrees. Both the strong absorption bands for the carbonyl groups $\left(1630,1446 \mathrm{~cm}^{-1}\right)$ in the IR spectrum and the signals in the ${ }^{1} \mathrm{H}$ - and ${ }^{13} \mathrm{C}$-NMR spectra indicated that $\mathbf{1}$ was characteristic of a peptide pattern. Detailed analyses of ${ }^{1} \mathrm{H},{ }^{13} \mathrm{C}, \mathrm{COSY}$, TOCSY, HSQC, and HMBC spectra led to the assignment of all of proton and carbon signals and revealed the presence of 5 conventional amino acids (Glu, Thr, Arg, Ile, and Val; Table 1). This was confirmed by amino acid analysis performed after hydrolyzing 1 with the $6 \mathrm{~N} \mathrm{HCl}$. It was also found that 1 contained one fatty acid (hexanoic acid), and two modified amino acids [3chloro- $N, O$-dimethylTyr(cdmTyr) and 3-amino-2-hydroxypiperidone(Ahp)].

The presence of Ahp moiety was identified by the sequential COSY correlations from the amide proton at $\delta 7.38$ to the methine proton at $\delta 4.92$ and the HMBC correlations of two methine protons at $\delta 4.43$ and 4.92 with the carbonyl carbon at $\delta 169.3$. Further, the proton at the $\alpha$ position of the Ile residue was found to be correlated with two carbons at $\delta$ 169.3 and 74.0 in the HMBC spectrum, thus indicating that the hemiaminal structure was formed from the Ile residue and glutamic acid. The Ahp group has often been found in the cyanobacterial species.

The protons in the downfield region were assigned based on the typical ABX-type proton-splitting pattern $[\delta 7.05$ $(1 \mathrm{H}, \mathrm{d}, J=8.6 \mathrm{~Hz}), 7.14 \mathrm{dd}(1 \mathrm{H}, \mathrm{dd}, J=8.6,1.9 \mathrm{~Hz})$ and 7.24 $(1 \mathrm{H}, \mathrm{d}, J=1.9 \mathrm{~Hz})]$ and the assignment of protons and carbons for one aromatic ring was done based on the HSQC and HMBC spectra. The HMBC spectrum showed correlations between two methine protons at $\delta 7.14$ and 7.24 and the methylene carbon at $\delta 32.9$ and between the methoxy singlet at $\delta 3.77$ and the oxygen-bearing quaternary carbon at $\delta$ 153.6. On the basis of the molecular formula containing a chlorine atom and a chlorine substituted carbon chemical shift in the aromatic ring, the remaining quaternary carbon $(\delta$ 121.3) was recognized to be bonded with a chlorine atom. On the other hand, another methyl singlet at $\delta 2.73$ showed the correlation with a carbonyl carbon at $\delta 169.7$ and the methine carbon at $\delta 60.4$ in the HMBC spectrum. This information indicated the presence of a new 3-chloro- $N, O$-dimethyltyrosine residue.

The sequence of amino acids was unequivocally established using HMBC correlations $\left({ }^{\mathrm{n}} J_{\mathrm{CH}}=5.0,8.0 \mathrm{~Hz}\right)$ between the amide proton of an amino acid and the carbonyl carbon of an adjacent amino acid, along with the $\alpha$ proton of Ile and two carbons in the Ahp residue, and NMe and the Ile-carbonyl carbon. Here, the amino proton for the Val residue was not observed but the connectivity of Val was secured by the HMBC correlation of the carbonyl carbon in the tyrosine residue with the $\alpha$ proton of Val. Moreover $\mathbf{1}$ had an ester linkage between the Thr and Val moieties, which was recognized by the HMBC correlation of the methine proton at $\delta$ 5.51 with the carbonyl carbon at $\delta 172.3$. This sequence of 1 was also supported by the ROESY data as well as the ESI MS/MS fragment peaks $(\mathrm{m} / \mathrm{z}: 329,485,711,936)$ after treatment with $\mathrm{NaOMe}$.

The absolute stereochemistry of the five conventional amino acids was determined as L-configuration by the acid hydrolysis of 1 and derivatization with Marfey's reagent, ${ }^{9)}$ 
Table 1. NMR Spectroscopic Data for Cyanopeptolin CB071 (1) (DMSO$\left.d_{6},{ }^{1} \mathrm{H}: 500 \mathrm{MHz},{ }^{13} \mathrm{C}: 125 \mathrm{MHz}\right)$

\begin{tabular}{|c|c|c|c|c|}
\hline \multirow{2}{*}{ Position } & \multicolumn{4}{|c|}{ Cyanopeptolin CB071(1) } \\
\hline & $\begin{array}{c}\delta_{\mathrm{C}} \\
(\mathrm{ppm})\end{array}$ & & $\begin{array}{c}\delta_{\mathrm{H}}(\mathrm{ppm}) \\
J(\mathrm{~Hz})\end{array}$ & $\begin{array}{l}\text { HMBC correlations } \\
\quad\left({ }^{\mathrm{n}} J_{\mathrm{CH}}=5,8 \mathrm{~Hz}\right)\end{array}$ \\
\hline HA 1 & 172.6 & & & \\
\hline 2 & 35.0 & & $2.13,2 \mathrm{H}, \mathrm{t}(7.3)$ & HA-1, -3 \\
\hline 3 & 24.9 & & $1.50,2 \mathrm{H}, \mathrm{m}$ & HA-2, -4 \\
\hline 4 & 30.8 & & $1.22,2 \mathrm{H}, \mathrm{m}$ & \\
\hline 5 & 21.8 & & $1.26,2 \mathrm{H}, \mathrm{m}$ & HA- $4,-6$ \\
\hline 6 & 13.8 & & $0.84,3 \mathrm{H}, \mathrm{t}(7.2)$ & HA-5 \\
\hline Glu 1 & 172.4 & & & \\
\hline 2 & 51.8 & & $4.39,1 \mathrm{H}, \mathrm{m}$ & Glu-1, $-3,-4$ \\
\hline 3 & 27.0 & $\mathrm{a}$ & $1.95,1 \mathrm{H}, \mathrm{m}: \mathrm{b} 1.74,1 \mathrm{H}, \mathrm{m}$ & Glu-2, $-4,-5$ \\
\hline 4 & 30.3 & & $2.27,2 \mathrm{H}, \mathrm{m}$ & Glu-3, -5 \\
\hline 5 & 174.0 & & & \\
\hline $\mathrm{NH}$ & & & $8.04,1 \mathrm{H}, \mathrm{d}(7.8)$ & HA-1 \\
\hline Thr 1 & 169.1 & & & \\
\hline 2 & 54.7 & & $4.64,1 \mathrm{H}$, brd $(8.3)$ & Thr-1, -4 \\
\hline 3 & 72.0 & & $5.51,1 \mathrm{H}$, br q $(6.6)$ & Thr-1, -4, Val-1 \\
\hline 4 & 17.8 & & $1.20,3 \mathrm{H}, \mathrm{d}(6.6)$ & Thr- $2,-3$ \\
\hline NH & & & $7.78,1 \mathrm{H}, \mathrm{d}(9.1)$ & Glu-1 \\
\hline $\operatorname{Arg} 1$ & 170.1 & & & \\
\hline 2 & 52.1 & & $4.28,1 \mathrm{H}, \mathrm{m}$ & \\
\hline 3 & 27.5 & $\mathrm{a}$ & $2.01,1 \mathrm{H}, \mathrm{m}: \mathrm{b} 1.46,1 \mathrm{H}, \mathrm{m}$ & \\
\hline 4 & 25.1 & & $1.46,2 \mathrm{H}, \mathrm{m}$ & Arg-3 \\
\hline 5 & 40.3 & & $3.09,2 \mathrm{H}, \mathrm{m}$ & Arg- $3,-4,-\mathrm{CN}$ \\
\hline $5-\mathrm{NH}$ & & & $7.56,1 \mathrm{H}, \mathrm{t}(5.5)$ & $\mathrm{Arg}-\mathrm{CN}$ \\
\hline $\mathrm{CN}$ & 156.7 & & & \\
\hline $\mathrm{NH}$ & & & $8.58,1 \mathrm{H}, \mathrm{d}(8.3)$ & Thr-1 \\
\hline Ahp 1 & 169.3 & & & \\
\hline 2 & 48.8 & & $4.43,1 \mathrm{H}, \mathrm{m}$ & Ahp-1, -3 \\
\hline 3 & 21.7 & $\mathrm{a}$ & $1.75,1 \mathrm{H}, \mathrm{m}: \mathrm{b} 2.56,1 \mathrm{H}, \mathrm{m}$ & Ahp-4 \\
\hline 4 & 29.7 & $\mathrm{a}$ & $1.77,1 \mathrm{H}, \mathrm{m}: \mathrm{b} 1.73,1 \mathrm{H}, \mathrm{m}$ & \\
\hline 5 & 74.0 & & $4.92,2 \mathrm{H}, \mathrm{brs}$ & \\
\hline $\mathrm{NH}$ & & & $7.38,1 \mathrm{H}, \mathrm{d}(9.1)$ & Ahp-1 \\
\hline $\mathrm{OH}$ & & & $6.16,1 \mathrm{H}, \mathrm{d}(2.7)$ & \\
\hline Ile 1 & 169.7 & & & \\
\hline 2 & 54.1 & & $4.37,1 \mathrm{H}, \mathrm{d}(9.9)$ & Ile-1,-3, Ahp-5 \\
\hline 3 & 32.9 & & $1.81,1 \mathrm{H}, \mathrm{m}$ & \\
\hline 4 & 23.7 & $\mathrm{a}$ & $1.09,1 \mathrm{H}, \mathrm{m}: \mathrm{b} 0.65,1 \mathrm{H}, \mathrm{m}$ & Ile- $-4^{\prime},-5$ \\
\hline $4^{\prime}$ & 13.8 & & $-0.14,3 \mathrm{H}, \mathrm{d}(6.4)$ & Ile- $2,3,-4$ \\
\hline 5 & 10.2 & & $0.62,3 \mathrm{H}, \mathrm{dd}(6.9,7.3)$ & Ile- $3,-4$ \\
\hline cdmTyr 1 & 169.1 & & & \\
\hline 2 & 60.4 & & $5.03,1 \mathrm{H}, \mathrm{dd}(11.5,2.9)$ & cdmTyr-1, -3 \\
\hline 3 & 32.9 & $\begin{array}{l}\mathrm{a} \\
\mathrm{b}\end{array}$ & $\begin{array}{l}3.22,1 \mathrm{H}, \text { brd }(14.2) \\
2.78,1 \mathrm{H}, \mathrm{dd}(14.2,11.5)\end{array}$ & cdmTyr-2, -4 \\
\hline 4 & 130.8 & & & \\
\hline 5 & 130.6 & & $7.24,1 \mathrm{H}, \mathrm{d}(1.9)$ & cdmTyr-3, -6, 7, -9 \\
\hline 6 & 121.3 & & & \\
\hline 7 & 153.6 & & & \\
\hline 8 & 113.1 & & $7.05,1 \mathrm{H}, \mathrm{d}(8.6)$ & cdmTyr-3, $-5,-6$ \\
\hline 9 & 129.4 & & $7.14,1 \mathrm{H}, \mathrm{dd}(8.6,1.9)$ & cdmTyr-4, $-6,-7$ \\
\hline $\mathrm{N}-\mathrm{CH}_{3}$ & 30.2 & & $2.73,3 \mathrm{H}, \mathrm{s}$ & Ile-1, cdmTry-2 \\
\hline $\mathrm{O}-\mathrm{CH}_{3}$ & 56.2 & & $3.77,3 \mathrm{H}, \mathrm{s}$ & cdmTyr-7 \\
\hline Val 1 & 172.3 & & & \\
\hline 2 & 56.3 & & $4.63,1 \mathrm{H}, \mathrm{m}$ & cdmTyr-1, Val-3, $-4,-4^{\prime}$ \\
\hline 3 & 29.7 & & $2.04,1 \mathrm{H}, \mathrm{m}$ & Val- $4,-4^{\prime}$ \\
\hline 4 & 19.2 & & $0.86,3 \mathrm{H}, \mathrm{d}(6.8)$ & Val-2, $-3,4^{\prime}$ \\
\hline $4^{\prime}$ & 17.7 & & $0.75,3 \mathrm{H}, \mathrm{d}(6.6)$ & Val- $2,-3,4$ \\
\hline NH & & & no (not observed) & \\
\hline
\end{tabular}

followed by HPLC analysis. In a similar manner, the stereochemistry of the 3-chloro- $\mathrm{N}, \mathrm{O}$-dimethylTyr residue was also assigned as L-configuration after comparison with the standard synthesized from $\mathrm{N}, \mathrm{O}$-dimethyl-D(L)-Tyr by using sulfuryl chloride. The stereochemistry of the last Ahp residue was determined through the oxidation of $\mathbf{1}$ by $\mathrm{CrO}_{3}$, followed

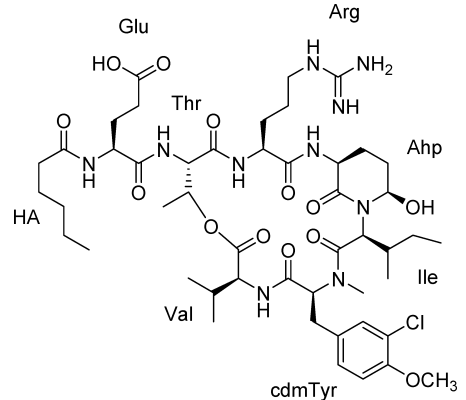

Fig. 1. Chemical Structure of Cyanopeptolin CB071 (1) from the Freshwater Cyanobacterium Aphanocapsa sp.

by the same advanced Marfey's method using LC-MS analysis. ${ }^{10)}$ The result obtained was L-configuration. Finally, the chiral center at position 5 on the Ahp residue was assigned as $R$-form by the ROESY experiment. This was deduced by the ROE cross peaks between the $\alpha$ proton at $\delta 4.43$ and the Ahp-3a proton at $\delta 1.75$ and between the Ahp-3b proton at $\delta$ 2.56 and the hydroxyl proton at $\delta 6.16$, indicating that the $\alpha$ proton and Ahp-5 proton are placed on the same side of the Ahp 6-membered ring.

Cyanopeptolin CB071 (1) was evaluated for trypsin and chymotrypsin-inhibitory activity and determined that $\mathbf{1}$ inhibited trypsin and chymotrypsin with $\mathrm{IC}_{50}$ values of $2.5 \mu \mathrm{M}$ and $64.8 \mu \mathrm{M}$, respectively. It is a new analogue to the Ahpcontaining depsipeptide and has the unusual amino acid residue 3-chloro- $\mathrm{N}, \mathrm{O}$-dimethylTyr. Many Ahp-containing cyclic depsipeptides show inhibitory activity against trypsin and chymotrypsin. Interestingly, trypsin inhibitors have the Arg-Ahp or Leu-Ahp sequence in the cyclic depsipeptides, while the chymotrypsin inhibitors have the Arg-Ahp, TrpAhp, or Leu-Ahp sequence. ${ }^{11)}$ Based on this structure and activity correlation, 1 was determined to have the Arg-Ahp sequence and found to show trypsin inhibition.

\section{Experimental}

General Optical rotation was measured using a JASCO P-1010 polarimeter with a $5 \mathrm{~cm}$ cell. An UV spectrum was acquired in methanol by using a Shimadzu 1700 spectrophotometer. An IR spectrum was recorded on a JASCO FT/IR 4100. NMR spectra were recorded in DMSO- $d_{6}$ on a Bruker DMX $600 \mathrm{MHz}$ spectrometer. A high resolution mass spectrum was obtained on a JEOL JMS-700 spectrometer, and LC-MS data for Marfey's analysis were acquired on a Finnigan LTQ instrument.

Biological Material Aphanocapsa sp. strain (KNU MAL-CB071) was originally isolated from Yongdam Lake, Korea, in July 2002. The strain KNU MAL-CB071 is currently maintained in the culture collection at Kunsan National University, Korea. Aphanocapsa is a genus of the unicellular fresh-water cyanobacteria that frequently forms colonies. Each colony consists of numerous sparsely or densely, irregularly arranged cells within a colonial mucilage. Each cell is more or less spherical, and without an individual gelatinous envelope. Cell division occurs by binary fission in two perpendicular planes in successive generations. ${ }^{12)}$ Sometimes the cells remain in twos or tetrads after division.

Culture Conditions The Aphanocapsa sp. strain KNU-MAL-CB071, was grown in five 20-1 PC-bottles with 1001 volume of modified CB medium with the following composition: $15 \mathrm{~g}$ of $\mathrm{Ca}\left(\mathrm{NO}_{3}\right)_{2} \cdot 4 \mathrm{H}_{2} \mathrm{O}, 10 \mathrm{~g}$ of $\mathrm{KNO}_{3}, 4 \mathrm{~g}$ of $\mathrm{MgSO}_{4} \cdot 7 \mathrm{H}_{2} \mathrm{O}, 5 \mathrm{~g}$ of $\beta$ - $\mathrm{Na}_{2}$ glycerophosphate, $0.01 \mathrm{mg}$ of vitamin $\mathrm{B}_{12}, 0.01 \mathrm{mg}$ of biotin, $1 \mathrm{mg}$ of thiamine $\mathrm{HCl}, 50 \mathrm{~g}$ of bicine, and $300 \mathrm{ml}$ PIV metals (where PIV metals are composed of $196 \mathrm{mg}$ of $\mathrm{FeCl}_{3} \cdot 6 \mathrm{H}_{2} \mathrm{O}$, $36 \mathrm{mg}$ of $\mathrm{MnCl}_{2} \cdot 4 \mathrm{H}_{2} \mathrm{O}, 22 \mathrm{mg}$ of $\mathrm{ZnSO}_{4} \cdot 7 \mathrm{H}_{2} \mathrm{O}, 4 \mathrm{mg}$ of $\mathrm{CoCl}_{2} \cdot 6 \mathrm{H}_{2} \mathrm{O}$, $2.5 \mathrm{mg}$ of $\mathrm{Na}_{2} \mathrm{MoO}_{4} \cdot 2 \mathrm{H}_{2} \mathrm{O}$, and $1 \mathrm{~g}$ of $\mathrm{Na}_{2}$ EDTA $\cdot 2 \mathrm{H}_{2} \mathrm{O}$ dissolved in 11 of distilled water) $\mathrm{pH} 7.5$.

The cells were grown at $20^{\circ} \mathrm{C}$ with gentle shaking of each 201 bottle every $12 \mathrm{~h}$. An irradiation of $60 \mu \mathrm{mol}$ photon $\mathrm{m}^{-2} \mathrm{~s}^{-1}$ from cool-white fluo- 
rescent lamps was continuously supplied to the surface of the vessels. The grown Aphanocapsa sp. cells were harvested from the early stationary phase by filtration using GF/F filters.

Extraction and Isolation The filtered cells were freeze-dried and extracted with $90: 10 \mathrm{MeOH}: \mathrm{H}_{2} \mathrm{O}$ solvent followed by concentration to dryness in vacuo. The extract was subjected to LH20 column chromatography, eluting with $100 \% \mathrm{MeOH}$ solvent at a flow rate of $1 \mathrm{ml} / \mathrm{min}$ to yield five fractions. The first fraction, eluted after $25 \mathrm{~min}$, was isolated with a $\mathrm{C}-18$ SPE cartridge by using $70 \% \mathrm{MeOH}$ to $100 \% \mathrm{MeOH}$. Further purification of 1 was performed by HPLC using a reversed phase silica column (YMC Pro $\mathrm{C} 18,25 \mathrm{~cm} \times 10 \mathrm{~mm}$ i.d.) with $30 \%$ aqueous $\mathrm{MeOH}$ at retention time of $35.5 \mathrm{~min}$.

Cyanopeptolin CB071 (1): Colorless glass; $[\alpha]_{\mathrm{D}}^{23}-70.9 \quad(c=0.05$, $\mathrm{MeOH})$. UV $\lambda_{\max }(\mathrm{MeOH}) \mathrm{nm}(\log \varepsilon) 227$ (4.02), 279 (3.52). ${ }^{1} \mathrm{H}-$ and ${ }^{13} \mathrm{C}-$ NMR, see Table 1. HR-FAB-MS $m / z: 1035.5259[\mathrm{M}+\mathrm{H}]^{+}$(Calcd for $\mathrm{C}_{48} \mathrm{H}_{76} \mathrm{O}_{13} \mathrm{~N}_{10} \mathrm{Cl}$ : 1035.5282)

Oxidation of 1 by $\mathrm{CrO}_{3} \quad \mathrm{CrO}_{3}$ oxidation was performed according to the procedure of Itou et al. ${ }^{10)} 50 \mu \mathrm{g}$ of 1 was dissolved in $500 \mu \mathrm{l}$ of a solution of $\mathrm{CrO}_{3}$ in $\mathrm{EtOH}(1 \mathrm{mg} / \mathrm{ml})$ and stirred at room temperature for $2 \mathrm{~h}$. Next, $500 \mu 1$ of water was added and the sample was stored at $4{ }^{\circ} \mathrm{C}$ for $12 \mathrm{~h}$. The reaction products were added to $10 \mathrm{ml}$ of $10 \% \mathrm{MeOH}$. This solution was loaded onto a small C-18 SPE cartridge equilibrated with $10 \% \mathrm{MeOH}$. The SPE column was flushed with $10 \%$ methanol, and the reaction products were eluted with $100 \%$ methanol. The eluate was evaporated to dryness and hydrolyzed as described above. The Glu and Ile obtained after hydrolysis enabled the determination of the configuration of the $\alpha$-position of Ahp and Ile.

ortho-Chlorination of $\mathrm{N}$-Me-4-methoxy-L-phenylalanine with Sulfuryl Chloride Sulfuryl chloride (10\% molar excess) was added to the $\mathrm{N}$-Me-4methoxy-L-phenylalanine $(209 \mathrm{mg} / 0.1 \mathrm{mmol})$ in acetic acid $(1 \mathrm{ml})$. The solution was allowed to react at room temperature for $24 \mathrm{~h}$. The reaction was monitored by thin-layer chromatography. After the reaction was completed, the solution was quenched with brine and ethyl acetate. The organic layer was separated and then the aqueous layer was extracted with ethyl acetate. The combined extract was evaporated under reduced pressure to yield the product. The crude compound was purified by HPLC (column: YMC AQ S$5,25 \mathrm{~cm} \times 10 \mathrm{~mm}$ i.d.; mobile phase: $\mathrm{H}_{2} \mathrm{O}: \mathrm{CH}_{3} \mathrm{CN}=90: 10$; flow rate: 2.0 $\mathrm{ml} / \mathrm{min}$; detection wavelength: $210 \mathrm{~nm}$ ).

Advanced Marfey's Method A peptide $(200 \mu \mathrm{g})$ was treated with $100 \mu \mathrm{l}$ of $6 \mathrm{~N} \mathrm{HCl}$ at $110^{\circ} \mathrm{C}$ for $1 \mathrm{~h}$. The reaction products obtained by lyophilization, and the residue were dissolved in $100 \mu \mathrm{l}$ of water and dried again. The dried hydrolysates were dissolved in $100 \mu \mathrm{l}$ of $1 \mathrm{M}$ sodium bicarbonate and separated into two vials. Twenty-five microliters of $1 \% 1$-fluoro2,4-dinitrophenyl-5-L-leucine amide (FDLA) in acetone was added to one part and $25 \mu \mathrm{l}$ of $1 \%$ D- and L-FDLA mixture in acetone to the other. Each solution was vortexed and incubated at $40{ }^{\circ} \mathrm{C}$ for $60 \mathrm{~min}$. After the reaction was quenched by the addition of $25 \mu 1$ of $2 \mathrm{~N} \mathrm{HCl}$, the reaction mixture was diluted with $100 \mu \mathrm{l}$ of methanol, and $10 \mu \mathrm{l}$ of each solution was analyzed by ESI LC-MS.

Trypsin and Chymotrypsin Inhibition Assay The Inhibitory activities against trypsin and chymotrypsin were determined as previously described, ${ }^{13)}$ using trypsin from bovine pancreas (Sigma T9201) and chymotrypsin from bovine pancreas (Sigma C4129). For the trypsin assay, a substrate solution of $0.5 \mathrm{~mm} N$-benzoyl-L-arginine ethyl ester (Sigma B4500) and $0.5 \mathrm{mg} / \mathrm{ml}$ enzyme solution was prepared in $67 \mathrm{~mm} \mathrm{NaH} \mathrm{NO}_{4}$ buffer with $\mathrm{pH}$ 7.6. Four serial test solutions were used to observe the variance in absorbance measured for $5 \mathrm{~min}$ at $253 \mathrm{~nm}$. The chymotrypsin assay was performed with $1.18 \mathrm{~mm}$ of $N$-benzoyl-L-tyrosine ethyl ester (Sigma B6125) as the substrate solution in $60 \%(\mathrm{v} / \mathrm{v}) \mathrm{MeOH}$ and $0.5 \mathrm{mg} / \mathrm{ml}$ enzyme solution in $1 \mathrm{~mm}$ of $\mathrm{HCl}$. The enzyme and serial test solutions were mixed with $80 \mathrm{~mm}$ of Tris- $\mathrm{HCl}$ solution with $2 \mathrm{M} \mathrm{CaCl}_{2}$, followed by addition of substrate solution. The increase in absorbance was measured using a spectrophotometer for $5 \mathrm{~min}$ at $256 \mathrm{~nm}$.

Acknowledgments This research was supported by a grant from Marine Biotechnology Project funded by Ministry of Land, Transport and Maritime Affairs, and the Brain Korea 21 (BK21) project, Ministry of Education \& Human Resources Development, Republic of Korea.

\section{References}

1) Rinehart K. L., Namikoshi M., Choi B. W., J. Appl. Phycol., 6, 159176 (1994).

2) Moore R. E., J. Ind. Microbiol., 16, 134-143 (1996).

3) Luesch H., Yoshida W. Y., Moore R. E., Paul V. J., Corbett T. H., J. Am. Chem. Soc., 123, 5418-5423 (2001).

4) Ishida K., Matuda H., Murakami M., Yamaguchi K., J. Nat. Prod., 60, 184-187 (1997).

5) Czarnecki O., Lippert I., Henning M., Welker M., Envion. Microbiol., 8, 77-87 (2006)

6) Ploutno A., Carmeli S., Tetrahedron, 58, 9949-9957 (2002).

7) Plaza A., Bewley C. A., J. Org. Chem., 71, 6898-6907 (2006).

8) Mattew S., Ross C., Rocca J., Paul V. J., Luesch H., J. Nat. Prod., 70, 124-127 (2007)

9) Marfey P., Carlsberg Res. Commun., 49, 591-596 (1984).

10) Itou Y., Ishida K., Shin H. J., Murakami M., Tetrahedron, 55, 68716882 (1999).

11) Yamaki H., Sitachitta N., Sano T., Kaya K., J. Nat. Prod., 68, 14-18 (2005).

12) Komárek J., Algae, 21, 349-375 (2006).

13) Linington R. G., Edwards D. J., Shuman C. F., McPhail. K. L., Matainaho T., Gerwick W. H., J. Nat. Prod., 71, 22-27 (2008). 